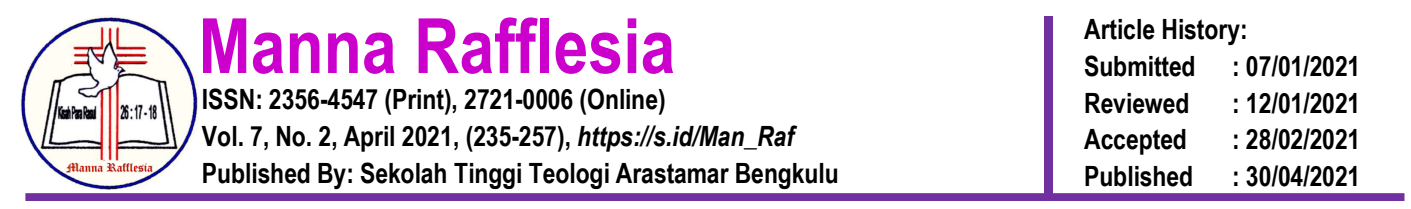

\title{
KAJIAN MANFAAT ALKITAB MENURUT 2 TIMOTIUS 3:16 DAN IMPLIKASINYA BAGI ORANG PERCAYA MASA KINI
}

\author{
Marthen $\left.\mathrm{Mau}^{1} *\right)$ \\ Sekolah Tinggi Teologi Injili Arastamar (SETIA) Ngabang $^{1}$ \\ *)Email Correspondence: marthenluthermau@gmail.com
}

\begin{abstract}
The only special revelation is the Bible which God has breathed as the main source for human learning, so that it can organize his life responsibly in service and life every day. Today some people think that the Bible is outdated and of no longer useful to mankind because this is the age of science, technology, and art. However, some people still believe that the Bible is very useful for mankind, therefore the Bible must be studied carefully so that the contents of the Bible are understood as a whole. This paper aims to encourage and inspire new enthusiasm for believers to be active in studying God's word that has been breathed by God because reading God's words can show that God is speaking to his readers. This paper uses a qualitative research method with a deep exegetical study approach. Therefore, this article provides a viewpoint for believers to be loyal in reading the Bible because the Bible is very useful for believers to imply in today's life.
\end{abstract}

Keywords: The Bible benefits, by implication, believers

Abstrak: Satu-satunya wahyu khusus adalah Alkitab yang telah dihembuskan oleh Allah sebagai sumber utama untuk dipelajari oleh manusia, sehingga dapat menata hidupanya secara bertanggung jawab dalam pelayanan dan kehidupan setiap hari. Dewasa ini sebagian orang menganggap bahwa Alkitab sudah ketinggalan zaman dan tidak bermanfaat lagi bagi umat manusia, karena zaman ini merupakan zaman ilmu pengetahuan, teknologi, dan kesenian. Tetapi sebagian orang tetap meyakini bahwa Alkitab sangat berguna bagi umat manusia karena itu Alkitab harus dipelajari secara saksama hingga dimengerti konten Alkitab secara menyeluruh. Tulisan ini bertujuan untuk mendorong dan membangkitkan semangat baru bagi orang percaya untuk giat dalam mempelajari firman-Nya yang telah dihembuskan oleh Allah sebab saat membaca firman Tuhan dapat menunjukkan bahwa Allah sedang berbicara kepada para pembacanya. Tulisan ini menggunakan metode penelitian kualitatif dengan pendekatan kajian eksegesis. Oleh karena itu, melalui artikel ini memberikan pandangan bagi orang percaya untuk memiliki loyalitas dalam membaca Alkitab karena Alkitab sangat bermanfaat bagi orang percaya untuk diimplikasikannya dalam kehidupan masa kini.

Kata Kunci: Manfaat Alkitab, implikasinya, orang percaya

\section{PENDAHULUAN}

Alkitab sebagai wahyu khusus yang dinyatakan Allah kepada manusia.

W. Gary Crampton berpendapat bahwa Allah menyatakan diri-Nya melalui Kitab

Suci karena Kitab Suci sebagai wahyu khusus yang dinyatakan bagi manusia 
dalam suatu unsur anthropomorfis. ${ }^{1}$ Perkataan ini dimaksudkan bahwa Allah mengomunikasikan diri-Nya kepada manusia dengan menggunakan bahasa manusia yang dinyatakan dalam keberadaan manusia. Perkataan yang ditulis para penulis ialah perkataan Allah yang dikomunikasikan-Nya secara sempurna, ${ }^{2}$ oleh karena Kitab Suci memiliki kesempurnaan sehingga tidak perlu disangsikan oleh manusia.

Perkataan Allah dalam firman-Nya sangat bermanfaat bagi kehidupan umat Tuhan, baik umat Tuhan pada masa lalu, masa kini dan masa mendatang. Alkitab sendiri menyatakan bahwa semua tulisan di dalamnya diilhamkan oleh Allah (2Tim. 3: 16; 1Ptr. 1: 20-21). Venema berkata, "Pengilhaman dalam penulisan Alkitab melibatkan inhale dan exhale. Istilah inhale berarti Roh Kudus mengomunikasikan kepada para penulis (author) firman Allah dengan sempurna (2Sam. 23: 2-3; Yes. 59: 21; Yer. 1: 9; Mat. 22: 42-44; Mrk. 12: 36; Kis. 4: 24; 28: 25). Sedangkan dalam exhale berarti para penulis menulis firman Allah sesuai dengan gaya penulisan pada zamannya artinya bahwa Allah secara sempurna berperan dalam penulisan firman-Nya dan para penulis juga secara sempurna berperan dalam menulis firman Allah. Roh Kudus sebagai Auctor Primarius (penulis pertama) dan para penulis sebagai Auctor Secundarius (penulis kedua)."”3

Pernyataan di atas dapat dijelaskan bahwa Allah memberikan pengilhaman kepada para penulis secara sempurna sehingga seluruh tulisannya adalah sempurna adanya, karena Allah tetap berperan secara sempurna maka firman Tuhan tetap kekal selama-selamanya. Firman Tuhan yang ditulis para penulis

1 W. Gary Crampton, Verbum Dei (Surabaya: Momentum, 2011), 38.

2 Yulius Enisman Harefa, "Studi Analisis Alkitab Dalam Menyikapi Biblical Criticism," Jurnal BMWGO 2, no. 1 (2017): 16.

3 Henk Venema, Kitab Suci Untuk Semua (Jakarta: YKBK, 2008), 17. 
dalam bahasa asli kemudian manusia diberikan tanggung jawab oleh Tuhan untuk menerjemahkan firman-Nya ke dalam berbagai bahasa tanpa salah (inerransi) dan tanpa keliru (infallibilitas).

Menurut Pelealu Samuel G, Alkitab adalah perkataan Allah yang tertulis sebagai bentuk pengakuan iman orang Kristen di sepanjang sejarah kekristenan. ${ }^{4}$ Orang percaya seharusnya mengakui secara iman dan pengetahuan yang dimilikinya bahwa satu-satunya sumber yang mampu menumbuh kembangkan iman adalah Firman Tuhan (bdk. Rm. 10: 17). Rasul Paulus memberikan nasihat kepada Timotius menurut 2Timotius 3: 16 bahwa Timotius sebagai seorang gembala di jemaat Efesus perlu berperan untuk mengajar, menyatakan kesalahan, memperbaiki kelakuan dan mendidik orang dalam kebenaran. Karena Jemaat Efesus merupakan anggota jemaat terbesar di Asia Kecil, sehingga rasul Paulus menempatkan Timotius sebagai seorang gembala muda yang memiliki kapabilitas dan loyalitas dalam pengabdiannya. Tulisan rasul Paulus kepada Timotius disebabkan oleh karena orang-orang Efesus menyeleweng dari kebenaran dan sibuk mengajarkan dongeng dan silsilah, serta sesat dalam omongan yang sia-sia. Orang Efesus tidak mengajarkan tertib hidup yang benar, hidup yang suci, dan hati yang murni tentang keselamatan dalam iman kepada Kristus Yesus (bdk. 1Tim. 1: 4-6). Karena itu, Timotius perlu mengajarkan jemaat Tuhan di Efesus supaya setia dalam mendengarkan, membaca, dan melakukan firman Tuhan untuk menumbuhkan iman di dalam Yesus Kristus sebab firman Tuhan bermanfaat bagi mereka. (2017): 48

${ }^{4}$ Pelealu Samuel G, "Pandangan Kaum Konservatif Tentang Alkitab," Jurnal BMW-GO 2, no. 1 
Pada zaman Yesus belum ada Alkitab secara lengkap seperti saat ini. Karena itu, Yesus Kristus memanggil dan memilih para rasul sebelum melaksanakan tugas pelayanan secara mandiri, maka perlu mendengarkan pengajaran yang benar secara langsung dari Yesus Kristus. Para pelayan Yesus Kristus pada masa kini perlu terus-menenrus membaca Alkitab. Membaca Alkitab sangatlah penting sebagai landasan untuk membangun dan mengajar orang lain (bdk. 1Tim. 4: 13) sebab tanpa membaca Alkitab, maka belum layak untuk membicarakan firman Tuhan. Suriani memberikan komentar bahwa seorang yang mengalami kerinduan untuk membaca Alkitab dan memelihara di dalam hidupnya, sehingga tidak pernah kehabisan perkataan firman Tuhan untuk disampaikan kepada orang lain. Membaca firman Tuhan merupakan suatu perkara terpenting bagi orang percaya karena itu bagi orang percaya yang tidak menyukai membaca Firman Tuhan, lebih baik baginya untuk tidak menjadi seorang pengajar Firman Tuhan. $^{5}$

Firman Tuhan bermanfaat bagi setiap orang percaya, maka penelitian ini bertujuan untuk mendorong orang percaya supaya giat dalam mempelajari firman Tuhan sebab Allah berbicara kepada para pembaca melalui Firman-Nya. Menurut Hales bahwa ketika setiap orang percaya ingin berbicara kepada Allah, maka perlu berdoa. Tetapi ketika setiap orang percaya ingin Allah berbicara kepadanya, maka harus menyelidiki tulisan suci (Firman Tuhan), karena firman-Nya dinyatakan melalui para nabi, raja, imam dan rasul-Nya. Kemudian Dia mengajar setiap orang percaya sesuai kehendak-Nya sehingga Firman Tuhan menjadi penolong rohani dalam setiap kehidupan orang percaya.

5 Suriani, "Mengajar Untuk Melipatgandakan Pekerja Kristus," Jurnal Luxnos 3, no. 1 (2017): 52. 
Alasan terpenting membaca Alkitab karena Alkitab adalah firman Tuhan yang merupakan sumber dasar terutama dan tertinggi yang sangat bermanfaat bagi para pembaca seperti tertulis di dalam 2Timotius 3: 16 bahkan untuk mengetahui segala karya Yesus selama melayani di bumi. Sebagian orang percaya menganggap bahwa Alkitab tidak perlu lagi didengar, dipelajari, dicamkan, diajarkan, dan diberitakan kepada khalayak ramai bahkan menganggap Alkitab sudah ketinggalan zaman disebabkan oleh karena ada interpretasi dikalangan teologi yang berpendapat bahwa Alkitab berisi firman Allah yang dimaksudkan bahwa sebagian orang yang memiliki perspektif mengenai esensi Alkitab yang dipercayai sebagai Firman Allah tanpa selamanya dapat diterima sebagai Firman Allah ketika perkataan firman yang dipelajari tidak berdampak untuk membangun kerohanian bagi para pembaca firman-Nya. ${ }^{6}$

Apabila Kitab-kitab Suci dianggap sebagai firman Tuhan yang tidak memberikan manfaat sama sekali bagi para pembaca, maka akibatnya ialah para pembaca akan menjadikan Alkitab sebagai buku biasa untuk disimpan pada tempat tertentu, seperti interpretasi sebagian teolog yang menganggap bahwa Alkitab merupakan buku cetak biasa yang dapat disamakan dengan buku-buku cetak lainnya yang disusun rapi di perpustakan. ${ }^{7}$ Alkitab adalah satu-satunya sumber dasar tertulis yang membenarkan manusia ketika dibaca/dipelajari secara terus-menerus. Tetapi sebagian orang beranggapan bahwa Alkitab merupakan satu bagian firman Allah yang dimaksudkan bahwa sebagian orang percaya menganggap bahwa Alkitab adalah Firman Allah tetapi di luar Kitab-kitab Suci

\footnotetext{
6 Misray Tunliu, "Eksistensi Kanon Alkitab dan Relevansinya di Era Globalisasi," PRUDENTIA: Jurnal Teologi dan Pendidikan Kristiani 1, no. 2 (2018): 148-165.

7 Tunliu, 152-153.
} 
ada kebenaran lain yang juga bisa dipercaya. ${ }^{8}$ Karena menganggap Alkitab sebagai salah satu firman, maka manusia dapat mengingkari firman Tuhan. Menurut Harefa bahwa ada sebagian orang yang mengingkari Kitab Suci sebagai sumber yang diinspirasikan oleh Allah. ${ }^{9}$

\section{METODE}

Penulis menggunakan metode penelitian kualitatif, dengan pendekatan eksegesis. Menggunakan kajian eksegesis karena fokus utama adalah menginterpretasikan teks 2Timotius 3: 16. Tujuan dari metode eksegesis adalah memperoleh pemahaman yang lebih baik mengenai kata-kata di dalam teks yang dieksegesis untuk memberikan makna. ${ }^{10}$ Jadi metode eksegesis pada penelitian ini mencari makna dari 2Timotius 3: 16 tentang kajian manfaat Alkitab. Dengan demikian 2Timotius 3: 16 dapat dipahami untuk memperoleh pemahaman yang benar sehingga dapat menarik sebuah implikasi bagi orang percaya masa kini.

\section{HASIL}

Hasil penelitian ini adalah pemahaman terhadap istilah dan kata penting dalam 2Timorius 3: 16, yaitu mengajar ( $\delta 1 \delta \alpha \sigma \kappa \alpha \lambda i ́ \alpha v)$, menyatakan kesalahan

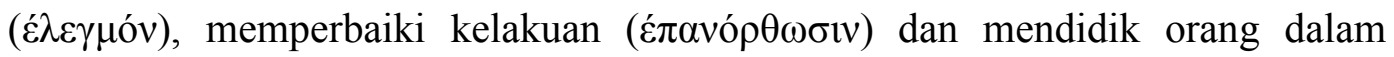

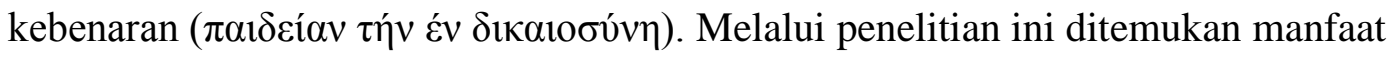
penting dari Alkitab firman Allah, yaitu: mengajar orang Percaya, menegur orang yang bersalah, memperbaiki kelakuan dan mendidik Orang Percaya. Selanjutnya penelitian ini juga memberikan implikasi penting, yaitu Pertama, Alkitab telah

8 Tunliu, 152.

9 Enisman Harefa, "Studi Analisis Alkitab Dalam Menyikapi Biblical Criticism." 16.

${ }^{10}$ Sonny Eli Zaluchu, "Strategi Penelitian Kualitatif Dan Kuantitatif Di Dalam Penelitian Agama," Evangelikal: Jurnal Teologi Injili dan Pembinaan Warga Jemaat 4, no. 1 (2020): 28-38, https://dx.doi.org/10.46445/ejti.v4i1.167. 
dihembuskan oleh Allah secara sempurna tanpa salah dan tanpa keliru. Sehingga Alkitab sungguh-sungguh dapat dipercaya kebenarannya. Kedua, Alkitab sangat bermanfaat bagi orang percaya. Menurut surat 2 Timotius bahwa rasul Paulus memerintahkan Timotius secara tidak langsung untuk loyal dalam membaca Alkitab secara terus-menerus. Alkitab merupakan wahyu khusus dari Allah untuk membimbing, menuntun, dan untuk memperbaiki kelakuan.

\section{PEMBAHASAN}

Pada pembahasan ini akan menjelaskan tentang makna dari istilah dan frasa penting dalam 2 Timotius 3: 16 serta implikasinya. Kata $\pi \alpha ́ \sigma \alpha$ (pasa) (ay. 16) merupakan kata tunggal tanpa kata sandang tertentu, yakni kata 'setiap', kata yang tidak dapat dihitung yakni 'seluruh'. Tunggal dengan kata sandang tertentu yakni seluruh, setiap sedangkan jamak yakni semua/segala. ${ }^{11}$ Jadi kata $\pi \alpha ́ \sigma \alpha$ (para) menurut teks 2 Timotius 3:16 yang cocok untuk digunakan karena diikuti dengan kata benda $\gamma \rho \alpha \phi \eta ́$, maka katanya adalah setiap/semua. Kata Yunani $\gamma \rho \alpha \phi \eta ́$ (graphe) yang berarti Alkitab, nas Alkitab. ${ }^{12}$ Alkitab dapat diterjemahkan dari kata asli yakni graphe yang berarti tulisan. Harefa berpendapat bahwa tulisan atau Kitab Suci diilhamkan oleh Allah. Semua tanda baca di dalam perkamen aslinya dituliskan bahwa semuanya merupakan inspirasi dari Allah, tetapi sebagian orang bisa saja membakar perkamen atau di makan oleh rayap, namun tulisan atau konten Kitab Suci tidak akan pernah hilang. ${ }^{13}$ Pernyataan ini dimaksudkan bahwa ketika ada orang tertentu yang berupaya untuk membakar naskah Alkitab tidak

11 B. F. Drewes, Kunci Bahasa Yunani Perjanjian Baru Kitab Injil Matius hingga Kitab Kisah Para Rasul (Jakarta: BPK Gunung Mulia, 2013), xxxviii.

12 Hasan Sutanto, Perjanjian Baru Interlinear dan Konkordansi Jilid 2 (Jakarta: LAl, 2010), 163-164.

${ }^{13}$ Enisman Harefa, "Studi Analisis Alkitab Dalam Menyikapi Biblical Criticism." 16. 
perlu dilawan karena yang terpenting adalah konten Kitab Suci yang sudah dipelajari oleh para pembaca dapat terukir di dalam hati sanubarinya.

Selanjutnya frasa 'segala tulisan' dapat diterjemahkan menjadi 'setiap tulisan' tetapi kedua-duanya benar sebab segala tulisan atau setiap tulisan dapat

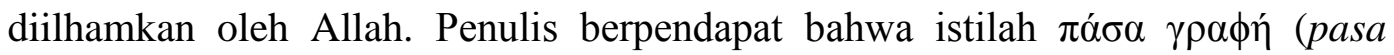
graphe) terjemahan yang sebaiknya ialah segala/semua tulisan di dalam Kitab Suci merupakan pengilhaman dari Allah. Jadi segala/semua tulisan dapat dihembuskan oleh Allah, maka sangat bermanfaat bagi para pembaca firman Tuhan. Kata $\theta \varepsilon o ́ \pi v \varepsilon v \sigma \tau o \varsigma$ (theopneustos) membicarakan mengenai fakta bahwa Alkitab dihembuskan keluar dari dalam diri Allah sedangkan ungkapan diinspirasikan berarti dihembuskan oleh Allah ke dalam diri para penulis Alkitab yakni manusia. Harefa berpendapat bahwa Roh Kudus adalah penulis atau author dari Alkitab. Alkitab bersifat autopistos, yakni membuktikan sendiri keotentikannya dengan menyinarkan sendiri wibawa ilahinya. ${ }^{14}$

Allah "mengilhamkan" kebenaran-Nya ke dalam pikiran para penulis Kitab Suci, sehingga para penulis menuliskan secara baik tanpa salah dan tanpa keliru. Bartholomeus Diaz N menyatakan bahwa kata ilham adalah sebuah proses dari Allah untuk menyampaikan kebenaran-Nya yang kekal. Kata ilham dalam bahasa Latin berarti "bernapas dalam" atau "ke dalam" (in dan spiro) dan ilham dalam bahasa Yunani yang artinya "napas Allah.” Allah memberikan Roh-Nya ke dalam diri para penulis Alkitab dan Dia membimbing mereka di dalam menuliskan Alkitab. Kata "inspirasi" berarti Allah menghembuskan Roh-Nya ke dalam manusia untuk memampukan mereka supaya menerima dan

14 Enisman Harefa, 16. 
mengomunikasikan kebenaran Ilahi tanpa kesalahan. ${ }^{15}$ Sesungguhnya, Roh Kudus memakai keunikan para penulis Alkitab, sehingga dapat menulis semua hal yang diinginkan oleh-Nya tanpa menambah, mengurangi maupun terjadi kesalahan, ${ }^{16}$ dan kekeliruan.

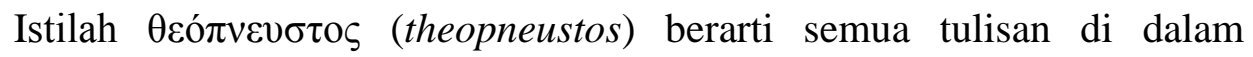
Alkitab merupakan nafas Tuhan atau perkataan yang diinspirasikan/diilhamkan oleh Allah. Karena itu, pada prinsipnya bahwa Alkitab dinafaskan oleh Allah kepada umat manusia untuk dibaca agar mengetahui rencana Tuhan dalam kehidupannya. Karena Tuhan menyatakan diri-Nya secara khusus melalui Alkitab yang telah diilhamkan oleh Allah tanpa campur tangan dari para penulis. Istilah кaí berarti "dan, juga, bahkan, dan khususnya, memang, bahwa, yaitu, ketika, maka, adapun, demikian juga, demikian, sehingga, malah, namun, walaupun,

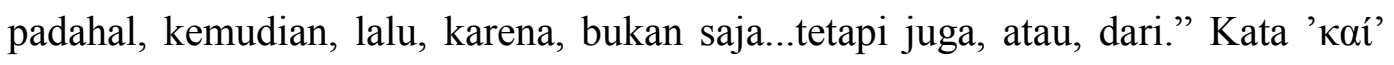
(kai) merupakan kata penghubung yang menjelaskan antara kalimat sebelumnya dan kalimat sesudahnya. Jadi terjemahan kata kaí yang benar dalam ayat ini

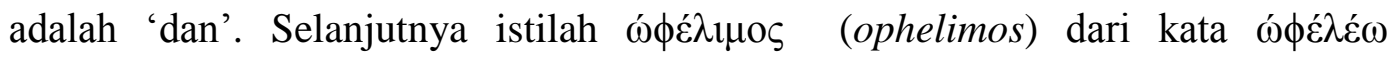

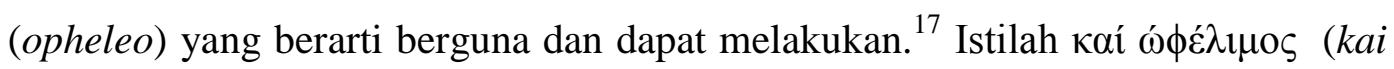

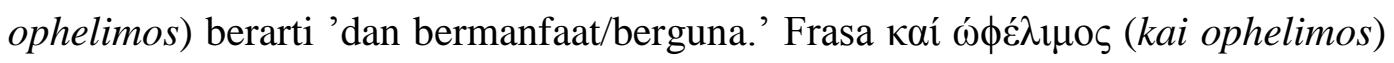
dalam temuan beberapa terjemahan mengindikasikan bahwa Alkitab sangat bermanfaat/berguna bagi umat manusia yang telah percaya kepada Yesus Kristus.

15 Bartholomeus Diaz N, "Artikel: Interpretasi: Dunia Mempertanyakan Apakah Alkitab Benar Diilhamkan Allah?," Jurnal Koinonia 9, no. 1 (2015): 14 , https://jurnal.unai.edu/index.php/koinonia/article/view/183.

16 Henry C. Thiessen dan Vernon Dorsken, Teologi Sistematika (Malang: Gandum Mas, 2012), 100.

17 Sutanto, Perjanjian Baru Interlinear dan Konkordansi Jilid 2, 781. 


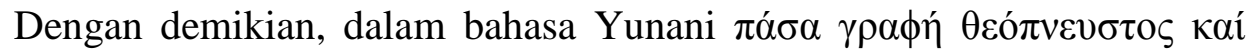
$\omega ́ \phi \varepsilon ́ \lambda ı$ (pasa graphe theopneustos kai ophelimos) apabila diterjemahkan secara harfiah berarti "segala tulisan yang dihembuskan oleh Allah dan sangat berguna."

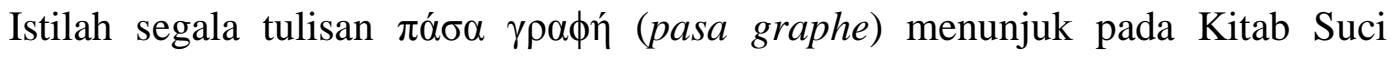
ísó $\gamma \rho \alpha ́ \mu \alpha \tau \alpha$ (hieragramata) (2Tim. 3: 15), sehingga artinya "segala tulisan yang terdapat dalam Kitab-kitab Suci." Tulisan-tulisan tersebut dikatakan sudah diilhamkan Allah artinya yang diilhamkan bukan hanya makna, berita atau kata, melainkan sampai kepada proses penulisan, maka ilham ilahi itu berlaku sehingga

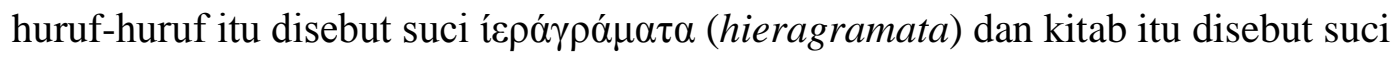
(2Tim. 3: 15). Arti harfiah dari diilihamkan ialah dihembuskan. Napas Allah menunjukkan kepada Allah sebagai Pencipta (Mzm. 33: 6; 104: 29-30; Yes. 42: 5; Kej. 2: 7; Yoh. 20: 22). Allah memberikan napas dan Roh-Nya, maka isi dunia tercipta. Dalam kaitan dengan Alkitab rasul Paulus menggunakan istilah nafas Allah yang menghembus, maka rasul Paulus ingin menegaskan Alkitab sebagai ciptaan Allah. Allah sendirilah yang menciptakan Alkitab melalui karya Roh Kudus-Nya yang bekerja sama dengan manusia pilihannya (1Kor. 3: 9$){ }^{18}$

\section{Mengajar ( $\delta \mathrm{\imath} \delta \alpha \sigma \kappa \alpha \lambda i ́ \alpha v)$}

Frasa 'untuk mengajar,' dari bahasa Yunani ialah $\pi \rho$ ś $\delta \delta \alpha \sigma \kappa \alpha \lambda i ́ \alpha v$ (pros didaskalian). Kata $\delta 1 \delta \alpha \sigma \kappa \alpha \lambda i ́ \alpha \nu$ (didaskalian) yang artinya pengajaran ${ }^{19}$ atau kata $\delta 1 \delta \alpha \sigma \kappa \alpha \lambda i ́ \alpha$ (didaskalia) yang artinya perbuatan mengajar, ajaran, doktrin. ${ }^{20}$ Istilah $\pi \rho o ́ \varsigma \delta 1 \delta \alpha \sigma \kappa \alpha \lambda i ́ \alpha v$ (pros didaskalian) dapat diterjemahkan menjadi "untuk mengajar" (Lih. Terjemahan Baru /TB, Alkitab Yang Terbuka / AYT, Shellabear YPPII, 1988), 97.

18 V Scheunemann, Apa Kata Alkitab Tentang Dogma Kristen (Batu: Departemen Multi-Media

19 Hasan Sutanto, Perjanjian Baru Interlinear dan Konkordansi Jilid 1 (Jakarta: LAI, 2010), 1135.

20 Sutanto, Perjanjian Baru Interlinear dan Konkordansi Jilid 2, 191. 
2010, Bahasa Indonesia yang Disederhanakan / BSD, New International Version / NIV, The Gideons), "untuk pengajaran" (Modified Indonesian Literal Translation / MILT), "untuk mengajarkan yang benar" (Bahasa Indonesia Sehari-hari / BIS) dan "untuk mengajarkan kebenaran kepada kita" (Firman Allah Yang Hidup / FAYH). Ungkapan $\pi \rho o ́ \varsigma ~ \delta i \delta \alpha \sigma \kappa \alpha \lambda i ́ \alpha v$ (pros disakalian) dapat dipahami bahwa manfaat dari Alkitab bagi umat manusia adalah untuk mengajarkan hal-hal benar dari Tuhan yang telah tertulis dalam Alkitab. Manase Gulo mengutip pendapat Haryono bahwa mengajar berarti suatu proses perbuatan atau peringatan yang dialami dan dilihat oleh seseorang untuk mendapatkan perubahan hidup. $^{21}$ Mengajar merupakan perintah rasul Paulus kepada Timotius untuk terus-menerus mengajarkan isi Alkitab karena Alkitab sangat bermanfaat kepada yang dilayani. Barclay menerangkan bahwa ajaran Kristen bisa mudah dimengerti ketika pelayan Kristus Yesus dapat memberi penjelasan mengenai pengharapan yang ada di dalam dirinya. Pelayan Kristus perlu studi Alkitab agar mampu menjelaskan tentang kebenaran firman Tuhan kepada orang percaya untuk memiliki dasar bertahan di dalam menghadapi penderitaan. ${ }^{22}$ Mengajar berarti memberi pelajaran dan melatih. ${ }^{23}$ Jadi Alkitab merupakan dasar pengajaran yang bersumber dari Allah sendiri untuk mengerti dan memahami kehendak-Nya, sehingga orang percaya wajib menggunakan Alkitab sebagai sumber pengajaran yang benar.

\section{Menyatakan Kesalahan ( $\dot{\lambda} \hat{\varepsilon} \gamma \mu \operatorname{có})$}

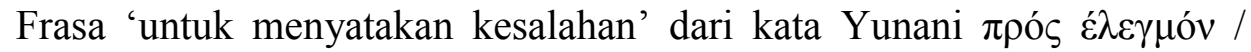
$\varepsilon \dot{\lambda} \varepsilon \gamma \mu$ ós (pros elegmon / elegmos) yang artinya untuk pembuktian

21 Manase Gulo, "Bertekun Dalam Pembacaan Kitab Suci Berdasarkan 1 Timotius 4:13," Manna Rafflesia 5, no. 1 (1 Januari 1970): 50-68, https://doi.org/10.38091/man_raf.v5i1.98.

22 William Barclay, Pemahaman Alkitab Setiap Hari Surat $1 \& 2$ Timotius, Titus, Filemon (Jakarta: BPK Gunung Mulia, 2001), 157.

${ }_{23}$ Anton M. Moeliono, Kamus Besar Bahasa Indonesia (Jakarta: Balai Pustaka, 1990), 23. 
kesalahan/teguran. ${ }^{24}$ Ungkapan menyatakan kesalahan pahaman dengan menjelaskan, menunjukkan, dan memperlihatkan ketidakbenaran sekaligus membuktikan bahwa setiap orang yang menyimpang dari kebenaran Tuhan perlu diberikan teguran nyata dan tegas supaya dapat memperlihatkan segala sesuatu yang benar menurut ukuran firman Tuhan. Pemakaian frasa "menyatakan kesalahan" dari kata Yunani $\varepsilon \dot{\lambda} \varepsilon \gamma \mu o ́ v$ (elegmon) dari kata $\varepsilon \dot{\lambda} \varepsilon \dot{\gamma} \chi \omega$ (elegxo) yang artinya teguran atau disiplin. Menurut Sutanto bahwa kata $\varepsilon \dot{\varepsilon} \gamma \chi \chi \omega$ (elegxo) dituliskan 17 kali dalam Perjanjian Baru dan memiliki arti menyingkapkan, membuktikan, menegur, menghukum dan memperbaiki. ${ }^{25}$ Kesalahan yang dimaksud adalah bicara mengenai dosa dan menolak pengajaran yang sesat; yang bisa saja terjadi di dalam seluruh kehidupan umat manusia maupun di dalam jemaat Tuhan di kota Efesus. Dengan demikian, manfaat Alkitab ialah menegur atau memperbaiki tindakan dosa dan kesalahan yang telah diperbuat oleh umat manusia, khususnya orang percaya karena orang percaya juga masih bisa berbuat kesalahan di dalam hidupnya. Karena itu, manfaat Alkitab ialah untuk menegur orang percaya apabila setia mendengar dan membaca esensi Alkitab secara menyeluruh.

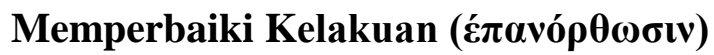

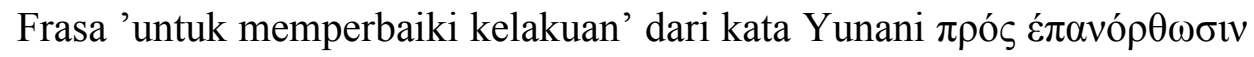

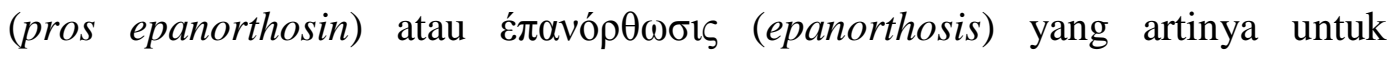

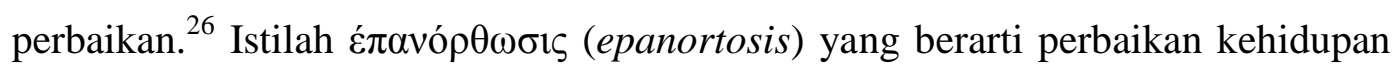
yang berkaitan erat dengan perilaku/tingkah laku. Kata memperbaiki dari kata

\footnotetext{
24 Sutanto, Perjanjian Baru Interlinear dan Konkordansi Jilid 1, 1135.

25 Sutanto, Perjanjian Baru Interlinear dan Konkordansi Jilid 2, 251.

${ }^{26}$ Sutanto, Perjanjian Baru Interlinear dan Konkordansi Jilid 1, 1135.
} 
dasar baik yang artinya tidak jahat kelakuannya, budi pekerti, dan jujur. ${ }^{27}$ Kata 'baik' dalam bahasa Yunani agathos berarti "baik" di dalam berbagai aspek kehidupan misalnya fisik, moral, kelakuan, budi pekerti, karakter, mental, kepribadian dan kerohanian. ${ }^{28}$ Jadi memperbaiki kelakuan ialah membenarkan perilaku melalui ajaran Firman Tuhan. Pernyataan memperbaiki kelakuan di dalam teks ini mengandung pemahaman bahwa firman Tuhan dapat bermanfaat untuk memperbaiki kelakuan/tingkah laku kehidupan manusia melalui kebenaran firman-Nya. Kelakuan manusia menjadi rusak dipengaruhi oleh roh-roh jahat, pergaulan yang buruk, dan pengajaran sesat. Karena itu, Alkitab atau firman Allah sebagai pedang Roh (Ef. 6: 17) yang sanggup untuk memperbaiki tingkah laku yang jahat bahkan firman Tuhan itu hidup dan kuat untuk memperbaiki dan membedakan antara yang baik dan jahat (bdk. Ibr. 4: 12) sebab itu Alkitab perlu dipelajari secara saksama pada setiap waktu.

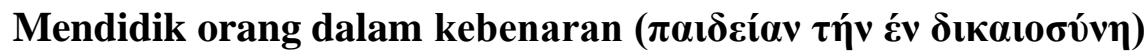

Frasa 'untuk mendidik orang dalam kebenaran' dari kata Yunani $\pi \rho o ́ \varsigma$ $\pi \alpha 1 \delta \varepsilon i ́ \alpha v \tau \eta ́ v ~ \varepsilon ́ v ~ \delta 1 \kappa \alpha 10 \sigma u ́ v \eta$ (pros paideian ten en dikaiosune) yang artinya untuk pendidikan dalam kesalehan. ${ }^{29}$ Kata $\pi \alpha \iota \delta \varepsilon i ́ \alpha v$ (paidean) diartikan sebagai

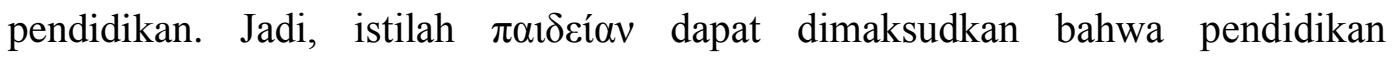
dipergunakan untuk mendidik orang dengan cara mengajar, menuntun, atau menghukum. ${ }^{30}$ Hal senada dikemukakan oleh Marthen Mau bahwa kata kerja $\pi \alpha \iota \delta \varepsilon v \omega$, paideuo yang berarti mendidik, menuntun, menghajar. ${ }^{31}$ Istilah

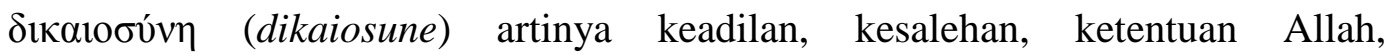

27 Moeliono, Kamus Besar Bahasa Indonesia, 79.

28 Djulius Thomas Bilo, Survive In God (Jakarta: Penerbit Views, 2016), 152.

${ }^{29}$ Sutanto, Perjanjian Baru Interlinear dan Konkordansi Jilid 1, 1135.

30 Sutanto, 562.

31 Marthen Mau, Pendidikan Nasional (Jakarta: Penerbit Views, 2016), 4. 
pembenaran, apa yang benar di hadapan Allah dan kebajikan. ${ }^{32}$ Guthrie dalam Kejar Hidup Laia berpendapat bahwa kata 'kebenaran' dalam Bahasa Yunani

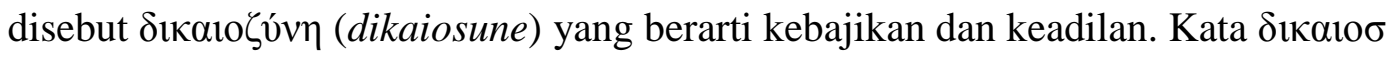

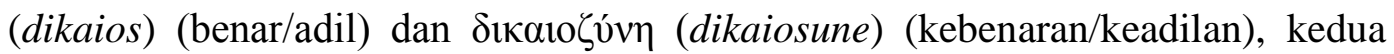
kata tersebut berasal dari akar kata yang sama dan bercorak hukum. ${ }^{33}$ Kata 'kebenaran' dapat dipahami bahwa suatu tindakan yang dilakukan berdasarkan kebenaran Tuhan. Kebenaran Allah tidaklah berhubungan dengan kebenaran keadilan-Nya, tetapi kebenaran hanya melalui iman. Pembenaran Allah ini

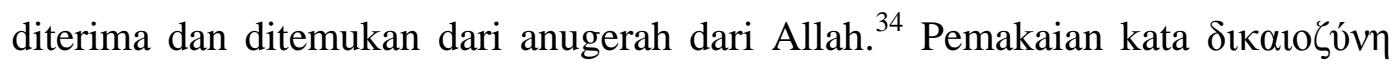
(dikaiosune) mengajarkan bahwa pusat dari segala kebenaran terletak dalam diri Tuhan Yesus Kristus yang telah dinyatakan di dalam firman Tuhan sehingga dapat dibaca/dipelajari secara saksama. Tindakan Allah untuk membenarkan tidak jauh berbeda dengan tindakan mengampuni (bdk. Rom. 4: 6-8). Kebenaran yang terdapat di dalam Kristus telah diilhamkan melalui Alkitab, sehingga ditempatkan pada posisi terpenting dalam pendidikan bagi umat-Nya.

\section{Manfaat Alkitab}

Berdasarkan hasil analisis eksegesis frasa dan istilah dalm 2Timotius 3: 16, ada beberapa manfaat Alkitab, yaitu: menganjar orang percaya, menegur orang yang bersalah, memperbaiki kelakukan dan mendidik orang percaya.

\section{Mengajar Orang Percaya}

Setiap orang memiliki animo yang besar untuk mengajar orang-orang lain. Dasar untuk mengajar orang lain tentu mengetahui esensi pengajaran secara baik.

32 W.R.F. Browning, A Dictionary of the Bible (Jakarta: BPK Gunung Mulia, 2009), 315.

33 Kejar Hidup Laia, "Makna Injil Berdasarkan Roma 1: 16-17 Dan Implementasinya Bagi Gereja Masa Kini," Manna Rafflesia 7, no. 1 (31 Oktober 2020): 1-21, https://doi.org/10.38091/man_raf.v7i1.133.

${ }^{34}$ Laia, 12. 
Membaca Alkitab merupakan cara yang sangat penting untuk mengetahui kehendak Tuhan di dalam Firman-Nya. Untuk membaca Alkitab dilakukan, baik di rumah secara pribadi, bersama anggota keluarga maupun di dalam persekutuanpersekutuan umum termasuk di tempat ibadah pada hari Minggu. Sesudah mengetahui, memahami, dan mengerti esensi dari Firman Tuhan yang telah dipelajari, maka dapat diajarkan kepada orang lain.

Para pelayan Yesus Kristus diperintahkan untuk memberikan pengajaran yang benar kepada orang-orang percaya pada masa kini. Yesus sebagai teladan dalam Alkitab dalam mengajarkan seluruh kebenaran kepada para rasul. ${ }^{35}$ Seorang pelayan Kristus wajib memiliki kemampuan dalam memberikan pengajaran yang benar. Pelayan Kristus Yesus harus menunjukkan sikap keteladanan yang baik dan berperan aktif dalam meneruskan pengajaran yang benar kepada orang-orang percaya yang dilayaninya.

\section{Menegur orang yang bersalah}

Pelayan Kristus juga perlu menegur orang yang bersalah yang hidupnya tidak sesuai dengan ajaran Alkitab. Menyatakan kesalahan artinya menunjukkan kesalahan, meyakinkan, menginsafkan dan menegur. ${ }^{36}$ King James Version (KJV) menerjemahkan dengan kata reprove artinya untuk membawa ke cahaya, untuk mengekspos, untuk menemukan kesalahan dengan benar demi kata, untuk menegur, mencaci, menegur, menunjukkan satu kesalahannya dan meminta penjelasan. ${ }^{37}$ Barclay mengungkapkan bahwa menyatakan kesalahan artinya

35 David Susilo Pranoto, "Karakteristik Hamba Tuhan Berdasarkan 2 Timotius 2:22-25," Manna Rafflesia 2, no. 2 (30 April 2016): 88-121, https://doi.org/10.38091/man_raf.v2i2.58.

36 Barclay M. Newman Jr, Kamus Yunani-Indonesia (Jakarta: BPK Gunung Mulia, 2004), 53.

${ }^{37}$ Kejar Hidup Laia, "Memahami Tugas Utama Hamba Tuhan Berdasarkan Surat II Timotius 4:1-5 Dan Aplikasinya Pada Masa Kini," Jurnal Teologi Berita Hidup 2, no. 2 (31 Maret 2020): 110-27, https://doi.org/10.38189/jtbh.v2i2.35. 
menyadarkan orang berdosa akan dosanya ${ }^{38}$ supaya secara radikal dapat meninggalkan dosanya dan hidup dalam kehidupan yang baru.

Pelayan Kristus perlu memiliki keberanian menegur setiap orang percaya yang hidup dalam dosa, ungkapan dosa disebut juga sebagai suatu kejahatan, maka pelayan Kristus Yesus harus menegur kejahatan. ${ }^{39}$ Bahwasanya tegoran yang diberikan oleh para pelayan Kristus Yesus kepada setiap orang percaya yang melakukan kesalahan bisa dalam bentuk disiplin. Roh Kudus menginspirasikan kepada rasul Paulus menuliskan sesuai dengan firman-Nya. Saat menegor orang yang bersalah tidak mengenal waktu kapan harus dilaksanakan dan tegoran harus dinyatakan. Bahkan menegor orang-orang yang bersalah supaya imannya bertumbuh sehat (bdk. Tit. 1: 13). Yesus juga mengajarkan untuk menegur di bawah empat mata, teguran yang dilandasi oleh asas saling percaya dan kasih. Oleh sebab itu, menegur, memperbaiki, mengajak kembali yang melakukan kesalahan selalu diletakkan dalam kerangka untuk menerima kembali setiap orang dalam kasih Kristus.

\section{Memperbaiki Kelakuan}

Alkitab adalah standar untuk mengatur tingkah laku setiap orang. Alkitab sanggup mengubah kelakuan manusia menjadi bersih dari segala kejahatan. Karena itu, orang percaya perlu menjaga kemurnian hidupnya setelah dibersihkan hidupnya oleh firman Allah (bdk. Yoh. 15: 3). Pelayan Kristus perlu memiliki pola pikir, perasaan dan tingkah laku yang baik dalam mendidik orang percaya. ${ }^{40}$ Banyak tokoh Alkitab yang memiliki kelakuan yang baik, Ronald W. Leigh menyatakan bahwa Yesus memiliki sifat lemah lembut (Mat. 11: 29). Rasul

${ }^{38}$ Barclay, Pemahaman Alkitab Setiap Hari Surat 1\&2 Timotius, Titus, Filemon, 317.

39 Thomas Bilo, Survive In God, 130.

40 Ad Rooijakkers, Mengajar dengan Sukses (Jakarta: Grasindo, 1993), 100. 
Paulus berlaku ramah terhadap jemaat di Tesalonika (1Tes. 2: 7). Rasul Paulus berkata bahwa pendeta atau penilik jemaat haruslah lemah lembut (1Tim. 3: 3). ${ }^{41}$ Karena itu pelayan Kristus perlu bersikap lemah lembut, ramah tamah dan memiliki kepedulian terhadap sesama manusia. Menurut Boyd K. Packer pengajaran firman Tuhan mampu mengubahkan karakter, sikap, perilaku, atau kelakuan. Pengajaran perilaku tidak sanggup untuk mengubahkan perilaku secara cepat, namun pengajaran Alkitab mampu mengubahkan perilaku secara baik karena itu Alkitab bisa menjadi buku perilaku untuk mengubahkan perilaku atau kelakukan yang buruk menjadi kelakuan yang baik.

Alkitab menjadi standar utama untuk dipakai di dalam memperbaiki kelakuan setiap orang. Religion in American Life menuliskan orang-orang yang menyukai membaca Alkitab dapat menolak pergaulan kehidupan yang jahat apabila dibandingkan dengan mereka yang tidak pernah membaca atau mempelajari firman Tuhan. Di penjara Lewes Remand Inggris seorang Pendeta telah berhasil mendorong sekitar 600 orang nara pidana untuk membaca atau mempelajari Alkitab berbulan-bulan dan akhirnya banyak yang bertobat. Para napi memberikan kesaksian bahwa Alkitab itu ternyata lebih baik daripada mabuk. $^{42}$ Jadi Alkitab memiliki pengaruh yang luar biasa untuk memperbaiki sikap, kelakuan dan karakter bagi kehidupan manusia yang menyukai dan mencintai untuk membaca Alkitab.

\section{Mendidik Orang Percaya}

Alkitab harus ditempatkan sebagai posisi tertinggi dalam pendidikan orang percaya tentang iman kepada Yesus Kristus dan hidup dalam kebenaran.

${ }^{41}$ Ronald W. Leigh, Melayani dengan Efektif (Jakarta: BPK Gunung Mulia, 1996), 28

42 Ryadi Pramana, "Manfaat Membaca Alkitab," www.gkikayuputih.or.id, GKI Kayu Putih, diakses 10 Oktober 2020, https://www.gkikayuputih.or.id/manfaat-membaca-alkitab/. 
Pertumbuhan iman seseorang terletak pada Alkitab karena iman orang percaya dapat bertumbuh ketika setia dalam membaca dan mendengarkan firman Tuhan (bdk. Rm. 10: 17). Orang percaya yang telah dewasa iman berperan penting mendidik orang Kristen yang belum dewasa iman. Ruat Diana mengutip pendapat Graendrof bahwa tujuan untuk mendidik orang percaya adalah untuk mendewasakan rohaninya atau imannya di dalam Yesus Kristus. ${ }^{43}$ Dalam penyelenggaraan pendidikan bagi orang percaya bertujuan untuk mendorong orang percaya secara terus-menerus agar giat mempelajari firman Tuhan, sebab firman Tuhan sebagai dasar untuk pertumbuhan imannya. Firman Tuhan mampu mengokohkan dan meneguhkan iman setiap orang percaya hingga menuju kepada kehidupan yang kekal.

\section{Implikasi Bagi Orang Percaya}

Berdasarkan hasil kajian eksegesis ada dua implikasi manfaat Alkitab. Pertama, Alkitab telah dihembuskan oleh Allah secara sempurna tanpa salah dan tanpa keliru. Ungkapan dihembuskan ada hubungan yang erat dengan inspirasi yang dimaksudkan bahwa Roh Kudus memimpin para penulis Alkitab, sehingga Alkitab dapat ditulis secara sempurna sesuai kehendak-Nya tanpa salah dan tanpa keliru dalam penulisannya. ${ }^{44}$ Sukono mengutip pendapat Sentot Sadono bahwa Alkitab diilhamkan oleh Allah dimaksudkan bahwa para penulis yang terpilih dapat diberikan kemampuan oleh Allah untuk menuliskan Kitab Suci tanpa mengandung unsur kesalahan dan kekeliruan (bdk. Yer. 30: 2; 2Tim. 3: 16-17; 2

43 Ruat Diana, "Prinsip Teologi Kristen Pendidikan Orang tua terhadap Anak di Era Revolusi Industri 4.0," BIA': Jurnal Teologi dan Pendidikan Kristen Kontekstual 2, no. 1 (24 Juni 2019): 27-39, https://doi.org/10.34307/b.v2i1.79.

${ }_{44}$ I Putu Ayub Darmawan dan Enggar Objantoro, "Signifikansi Ineransi Alkitab Bagi Pendidikan Kristen," Sola Scriptura: Jurnal Teologi 1, no. 1 (2020): 36-52. 
Ptr.1: 19-21). ${ }^{45}$ Alkitab dihembuskan oleh Allah karena itu Alkitab harus dibaca/dipelajari oleh orang percaya tanpa berhenti. Menurut Tunliu Alkitab adalah Wahyu khusus dari Allah yang absolute. ${ }^{46}$

Kedua, Alkitab sangat bermanfaat bagi orang percaya. Menurut surat 2 Timotius rasul Paulus memerintahkan Timotius secara tidak langsung untuk loyal dalam membaca Alkitab secara terus-menerus. Alkitab merupakan wahyu khusus dari Allah untuk membimbing, menuntun, dan untuk memperbaiki kelakuan. Menurut Kartina Melly manfaat membaca Alkitab yakni: Pertama, Firman Tuhan menuntun orang percaya agar menerima keselamatan kekal (bdk. 2Tim. 3: 15; Mat. 4: 4). Kedua, Firman Tuhan menguatkan dan meneguhkan iman orang percaya supaya kuat dalam menghadapi berbagai penderitaan dan pencobaan (bdk. 1Yoh. 2: 14). Ketiga, Firman Tuhan memberi kepastian keyakinan kepada orang percaya agar tetap berpegang pada kehidupan kekal yang telah dianugerahkan oleh Tuhan (bdk. 1Yoh. 5: 13). Keempat, Firman Tuhan terusmenerus menguatkan dan menumbuhkan iman orang percaya melalui doa (bdk. Yoh. 15: 7; Rm. 10: 17). Kelima, Kebenaran firman Tuhan berkuasa untuk menyucikan dan menguduskan orang percaya (bdk. Yoh. 17: 17; 15: 3; Mzm. 119: 9). Keenam, Kebenaran firman Tuhan dapat menopang dan menguatkan hati orang percaya (bdk. Mzm. 19: 9; Yoh. 16: 33). Ketujuh, orang percaya tidak akan merasa takut karena firman Tuhan memberi keberanian kepadanya (bdk. Mzm. 119: 105; Yos. 1: 8). ${ }^{47}$

45 Djoko Sukono, "Alkitab: Penyataan Allah Yang Dilihamkan," PASCA: Jurnal Teologi dan Pendidikan Agama Kristen 15, no. 1 (30 November 2019): 28-34, https://doi.org/10.46494/psc.v15i1.66.

46 Tunliu, "Eksistensi Kanon Alkitab dan Relevansinya di Era Globalisasi." 153.

47 Kartina Melly, "Manfaat dan Keuntungan Membaca Alkitab," livingwatersweb.com, Living Waters, 2020, livingwatersweb.com. 
Ketiga, membaca Alkitab memerlukan pimpinan Roh Kudus yang menjadikan kemauannya siap untuk membaca dengan jujur dan juga untuk menerima apa yang dibacanya. Gulo mengutip pendapat Bruggen bahwa orang yang membaca Alkitab namun tetap menjadi orang Kristen yang belum dewasa adalah orang yang tidak membaca dengan baik. ${ }^{48}$ Venema dalam Gulo berpendapat bahwa orang yang hanya membaca Alkitab secara selektif, belum membaca Alkitab. Pembaca seperti itu tidak berhak memberi tafsiran, penilaian, atau tanggapan. Janganlah orang seperti itu memberanikan diri naik mimbar lalu berbicara dalam nama Tuhan atau berkhotbah dengan kuasa Roh Kudus. Alkitab memperkenalkan diri sebagai buku yang merupakan satu kesatuan, dimana setiap kitab berfungsi sebagai bagian yang masing-masing menekankan kesatuan Alkitab di bidang isi, visi, dan konsepsi, yakni Kristus (bdk. Luk 24: 32, 44-45; Yoh 5: 39). ${ }^{49}$ Berdasarkan penjelasan di atas, maka penulis dapat menyimpulkan orangorang yang hanya ingin membaca Alkitab ketika menunggu kiriman renungan harian melalui wa, facebook, koran, majalah dan media sosial lainnya maka belum sepenuhnya membaca Alkitab. Membaca Alkitab merupakan tugas dan kewajiban setiap orang percaya. Karena setiap orang percaya harus membaca Alkitab sebab Alkitab yang dibaca/dipelajari adalah kebenaran Allah dan waktu membaca Alkitab berarti menjalin hubungan yang baik secara pribadi dengan Tuhan.

\section{KESIMPULAN}

Berdasarkan kajian eksegesis 2Timotius 3: 16, maka dapat diketahui bahwa Alkitab adalah sumber dasar terutama dan tertinggi yang telah diilhamkan

48 Manase Gulo, "Membangun Spiritualitas Berdasarkan Surat 1 Timotius 4: 12," Manna Rafflesia 1, no. 1 (31 Oktober 2014): 36-53, https://doi.org/10.38091/man_raf.v1i1.44.

49 Gulo. 
atau dihembuskan Allah kepada para penulis untuk menuliskan secara baik tanpa kesalahan dan kekeliruan. Alkitab yang telah diilhamkan oleh Allah sangat berguna bagi kehidupan umat manusia. Oleh karena itu perlu mengajarkan kebenaran Firman Tuhan, menegur atau mendisiplinkan orang percaya yang berbuat kesalahan, memperbaiki perilaku yang menyimpang dari pengajaran yang benar. Pengajaran yang benar menurut Alkitab harus memberikan pengaruh kepada orang percaya, baik di keluarga, gereja, sekolah dan lingkungan. Dengan demikian, Alkitab tetap berlaku pada semua zaman karena Alkitab adalah satusatunya sumber dasar yang mampu mengoreksi gaya hidup umat manusia, mempertahankan supaya kelakuan tetap bersih, dan menuntun manusia supaya tidak menyimpang dari perintah-perintah-Nya. Maka Alkitab tetap bermanfaat dan relevan bagi orang percaya masa kini.

\section{DAFTAR PUSTAKA}

Barclay, William. Pemahaman Alkitab Setiap Hari Surat 1\&2 Timotius, Titus, Filemon. Jakarta: BPK Gunung Mulia, 2001.

Browning, W.R.F. A Dictionary of the Bible. Jakarta: BPK Gunung Mulia, 2009.

Darmawan, I Putu Ayub, dan Enggar Objantoro. "Signifikansi Ineransi Alkitab Bagi Pendidikan Kristen.” Sola Scriptura: Jurnal Teologi 1, no. 1 (2020): 36-52.

Diana, Ruat. "Prinsip Teologi Kristen Pendidikan Orang tua terhadap Anak di Era Revolusi Industri 4.0." BIA': Jurnal Teologi dan Pendidikan Kristen Kontekstual 2, no. 1 (24 Juni 2019): 27-39. https://doi.org/10.34307/b.v2i1.79.

Diaz N, Bartholomeus. "Artikel: Interpretasi: Dunia Mempertanyakan Apakah Alkitab Benar Diilhamkan Allah?” Jurnal Koinonia 9, no. 1 (2015): 14. https://jurnal.unai.edu/index.php/koinonia/article/view/183.

Enisman Harefa, Yulius. "Studi Analisis Alkitab Dalam Menyikapi Biblical Criticism." Jurnal BMW-GO 2, no. 1 (2017): 16. 
F. Drewes, B. Kunci Bahasa Yunani Perjanjian Baru Kitab Injil Matius hingga Kitab Kisah Para Rasul. Jakarta: BPK Gunung Mulia, 2013.

Gary Crampton, W. Verbum Dei. Surabaya: Momentum, 2011.

Gulo, Manase. "Bertekun Dalam Pembacaan Kitab Suci Berdasarkan 1 Timotius 4:13." Manna Rafflesia 5, no. 1 (1 Januari 1970): 50-68. https://doi.org/10.38091/man_raf.v5i1.98.

—. "Membangun Spiritualitas Berdasarkan Surat 1 Timotius 4: 12." Manna Rafflesia 1, no. $1 \quad$ (31 Oktober 2014): 36-53. https://doi.org/10.38091/man_raf.v1i1.44.

Laia, Kejar Hidup. "Makna Injil Berdasarkan Roma 1: 16-17 Dan Implementasinya Bagi Gereja Masa Kini." Manna Rafflesia 7, no. 1 (31 Oktober 2020): 1-21. https://doi.org/10.38091/man_raf.v7i1.133.

. "Memahami Tugas Utama Hamba Tuhan Berdasarkan Surat II Timotius 4:1-5 Dan Aplikasinya Pada Masa Kini." Jurnal Teologi Berita Hidup 2, no. 2 (31 Maret 2020): 110-27. https://doi.org/10.38189/jtbh.v2i2.35.

M. Newman Jr, Barclay. Kamus Yunani-Indonesia. Jakarta: BPK Gunung Mulia, 2004.

Mau, Marthen. Pendidikan Nasional. Jakarta: Penerbit Views, 2016.

Melly, Kartina. "Manfaat dan Keuntungan Membaca Alkitab." Livingwatersweb.com. Living Waters, 2020. livingwatersweb.com.

Moeliono, Anton M. Kamus Besar Bahasa Indonesia. Jakarta: Balai Pustaka, 1990.

Pramana, Ryadi. "Manfaat Membaca Alkitab.” Www.gkikayuputih.or.id. GKI $\begin{array}{lllll}\text { Kayu } & \text { Putih. } & \text { Diakses } & 10 & \text { Oktober }\end{array}$ https://www.gkikayuputih.or.id/manfaat-membaca-alkitab/.

Pranoto, David Susilo. "Karakteristik Hamba Tuhan Berdasarkan 2 Timotius 2:22-25." Manna Rafflesia 2, no. 2 (30 April 2016): 88-121. https://doi.org/10.38091/man_raf.v2i2.58.

Rooijakkers, Ad. Mengajar dengan Sukses. Jakarta: Grasindo, 1993.

Samuel G, Pelealu. "Pandangan Kaum Konservatif Tentang Alkitab." Jurnal BMW-GO 2, no. 1 (2017): 48.

Scheunemann, V. Apa Kata Alkitab Tentang Dogma Kristen. Batu: Departemen Multi-Media YPPII, 1988. 
Sukono, Djoko. "Alkitab: Penyataan Allah Yang Diilhamkan.” PASCA : Jurnal Teologi dan Pendidikan Agama Kristen 15, no. 1 (30 November 2019): 28-34. https://doi.org/10.46494/psc.v15i1.66.

Suriani. "Mengajar Untuk Melipatgandakan Pekerja Kristus." Jurnal Luxnos 3, no. 1 (2017): 52.

Sutanto, Hasan. Perjanjian Baru Interlinear dan Konkordansi Jilid 1. Jakarta: LAI, 2010.

—. Perjanjian Baru Interlinear dan Konkordansi Jilid 2. Jakarta: LAI, 2010.

Thiessen, Henry C., dan Vernon Dorsken. Teologi Sistematika. Malang: Gandum Mas, 2012.

Thomas Bilo, Djulius. Survive In God. Jakarta: Penerbit Views, 2016.

Tunliu, Misray. "Eksistensi Kanon Alkitab dan Relevansinya di Era Globalisasi." PRUDENTIA: Jurnal Teologi dan Pendidikan Kristiani 1, no. 2 (2018): 148-63.

Venema, Henk. Kitab Suci Untuk Semua. Jakarta: YKBK, 2008.

Zaluchu, Sonny Eli. "Strategi Penelitian Kualitatif Dan Kuantitatif Di Dalam Penelitian Agama." Evangelikal: Jurnal Teologi Injili dan Pembinaan Warga Jemaat 4, no. 1 (2020): 28-38. https://dx.doi.org/10.46445/ejti.v4i1.167. 